\title{
Effect of oestradiol replacement in ovariectomized chickens on pituitary LH concentrations and concentrations of mRNAs encoding LH $\beta$ and $\alpha$ subunits
}

\author{
O. Terada, K. Shimada* and N. Saito \\ Laboratory of Animal Physiology, School of Agriculture, Nagoya University, Chikusa, Nagoya 464-01, \\ Japan
}

\begin{abstract}
Plasma concentrations of oestradiol and LH and steady-state pituitary concentrations of the mRNAs encoding the LH $\beta$ and $\alpha$ subunits in the gland were measured at intervals of 1 month for 5 months in female chickens. In addition, feedback regulation by oestradiol of concentrations of mRNAs encoding these LH subunits was studied in ovariectomized young (3-week-old) and adult hens. Concentrations of the mRNAs encoding the $\mathrm{LH} \beta$ and $\alpha$ subunits increased significantly before sexual maturity and the changes were highly correlated with increases in plasma and pituitary concentrations of LH. Ovariectomy significantly reduced circulating plasma concentrations of oestradiol but increased pituitary concentrations of mRNAs encoding LH $\beta$ and $\alpha$ subunits and pituitary and plasma concentrations of LH in adult laying hens. In addition, in 3-week-old chickens, ovariectomy induced an increase in plasma and pituitary gland concentrations of LH. This ovariectomyinduced mRNA expression and tissue and plasma increases of LH were prevented by oestradiol replacement. These data suggest that a negative feedback mechanism by ovarian oestradiol inhibits LH release from the pituitary and pituitary LH biosynthesis in chickens.
\end{abstract}

\section{Introduction}

LH is one of the heterodimeric glycoprotein hormones synthesized in the pituitary gland of birds, mammals, and other orders of animals. It consists of an $\alpha$ subunit and a $\beta$ subunit wherein the $\alpha$ subunit is common for LH, FSH and thyroid-stimulating hormone, while the $\beta$ subunit is chemically and biologically unique in each of these hormones. Unlike in mammals (Haisenleder et al., 1993), little is known about the regulation of the expression, synthesis, storage or secretion of avian mRNA encoding $\mathrm{LH}$. The characterization of chicken cDNAs encoding LH $\alpha$ and $\beta$ subunits (Noce et al., 1989; Foster et al., 1992) allowed progress to be made in understanding the physiological regulation of avian LH synthesis and release. Several studies have examined the role of photoperiod on the stimulation of LH subunit gene expression and LH release in birds (Noce et al., 1989; Petrowski et al., 1993; Kubokawa et al., 1994).

Wilson and Sharp (1976) demonstrated that both oestradiol and progesterone are necessary to prime the pituitary to effect a positive LH feedback mechanism and that the preovulatory surge in LH release is due to increasing progesterone and not oestradiol. Recently, negative feedback effects of gonadal steroids on $\mathrm{LH}$ release and synthesis have been examined. For example, Luck and Scanes (1980) showed that in cultures of chicken pituitary cells, progesterone had no effect on

*Correspondence and reprint requests.

Revised manuscript received 1 April 1997.
LH release and testosterone enhanced LH release, whereas oestradiol reduced $\mathrm{LH}$ release and prevented stimulation by GnRH. Furthermore, in turkeys, ovariectomy results in a stimulation of plasma LH concentrations and expression of the LH $\beta$ subunit gene (Petrowski et al., 1993), which suggests that ovarian steroids may suppress LH release and gene expression. Similarly, in mammals, ovariectomy is associated with an increase in mRNAs encoding LH $\alpha$ and $\beta$ subunits in the pituitary gland which can be inhibited by oestradiol treatment (Papavasiliou et al., 1986; Fallest et al., 1995). Taken together, these data suggest that both positive and negative feedback effects of ovarian steroids on $\mathrm{LH}$ release and synthesis may occur in chickens.

Plasma concentrations of LH increase before sexual maturity in chickens (Senior, 1974; Sharp, 1975; Williams and Sharp, 1977; Sharp et al., 1977; Tanabe et al., 1981; Itoh et al., 1988); however, the relationship between $\mathrm{LH}$ release and synthesis and ovarian steroids has not been extensively characterized in immature chickens. Accordingly, this study was conducted to study the expression of $\mathrm{LH} \alpha$ and $\beta$ subunits during development (up to 5 months of age, the onset of egg laying) and to relate this information to the content of LH in the pituitary gland and to circulating concentrations of LH in the blood. In addition, since we hypothesized that ovarian oestradiol would have a negative feedback effect on these parameters, the effects of oestradiol replacement in ovariectomized, sexually immature and mature laying hens were examined. 


\section{Materials and Methods}

\section{Animals and collection of tissues and plasma}

Female chicks of a White Leghorn strain, purchased from Hattori Hatchery Co. Ltd, Nagoya and raised under standard conditions with food and water ad libitum and $14 \mathrm{~h}$ light and $10 \mathrm{~h}$ darkness, were used in the following experiments.

In Expt I, groups of five to ten birds were killed for collection of blood and tissue samples at 1, 2, 3, 4 and 5 months of age. In Expt II, 3-week-old females were divided into the following groups. (1) Sham operated group (sham) $(n=5)$ : birds were incised through the abdominal skin and muscle to expose and handle the ovary and two empty Silastic tubings (o.d. $3.18 \mathrm{~mm}$; i.d. $1.57 \mathrm{~mm}$; length $30 \mathrm{~mm}$ ) were implanted under the skin. (2) Ovariectomized group (OVX) $(n=5)$ : birds were ovariectomized by destroying ovarian tissues by local application of small pieces of dry ice and two empty Silastic tubings were implanted as above. (3) Ovariectomized and oestradiol-implanted group (OVX-E2) $(n=5)$ : birds were ovariectomized as in group (2) and two Silastic tubings containing oestradiol (Sigma, St Louis, MO) were implanted under the skin. The surgery was conducted under anaesthesia with sodium pentobarbital (20 $\mathrm{mg} \mathrm{kg}^{-1}$ bodyweight) and incisions were closed with silk sutures. Birds were killed 5 days after the surgery. The pituitary glands and blood were collected and birds were inspected for completeness of ovariectomy after the experiment.

Eighteen-month-old laying hens were also divided into the following groups: (1) sham $(n=5),(2)$ OVX $(n=5)$ and (3) OVX-E2 $(n=5)$. The same treatments as in the pullets were conducted in the laying hens except for the ovariectomy. Ovariectomy was performed by the removal of large and small yellow follicles and as many white follicles as possible. The remaining ovarian tissues were destroyed by applying pieces of dry ice.

\section{Extraction of RNA}

Pituitary glands were homogenized in $100 \mu \mathrm{l}$ of a solution containing $0.5 \%(\mathrm{w} / \mathrm{v})$ Nonidet-P40 (Sigma, St Louis, MO), $10 \mathrm{mmol}$ Tris $-\mathrm{HCl} \mathrm{l}^{-1}$ and $1 \mathrm{mmol}$ EDTA $\mathrm{I}^{-1}$. Aliquots (10 $\mu$ l) of the homogenate were stored at $-20^{\circ} \mathrm{C}$ and assayed for hormone content by radioimmunoassay (Kansaku et al., 1994). RNA was extracted from the remaining homogenate according to the methods described by Chomczynski and Sacchi (1987). The amount of total RNA was estimated by spectrophotometry (Beckman Instruments Inc., Fullerton, CA).

\section{${ }^{32}$ P-labelled hormone $c D N A$ probe}

Chicken cDNAs encoding LH $\beta$ and $\alpha$ subunits (kind gifts from S. Ishii, Waseda University and D. N. Foster, University of Minnesota, respectively) were labelled by a random priming labelling kit (Boehringer-Mannheim, Mannheim) as described by Shimada et al. (1991) and used as a probe for northern blot hybridization.

\section{Northern blot hybridization}

Aliquots of total cellular RNA $(5 \mu \mathrm{g})$ were denatured with formaldehyde, fractionated by electrophoresis in $1.2 \%(\mathrm{w} / \mathrm{v})$ agarose gel, and transferred to Hybond- ${ }^{+}$membrane (Amersham, Inc., Amersham, Bucks) as described by Kansaku et al. (1994).

Membranes were prehybridized for $2 \mathrm{~h}$ in hybridization buffer, and the denatured radiolabelled cDNA probe was added to hybridization buffer. Membranes were then hybridized for a further $20 \mathrm{~h}$ at $42^{\circ} \mathrm{C}$. After hybridization, membranes were washed in $1 \times \mathrm{SSC} / 0.1 \%$ SDS for $30 \mathrm{~min}$ at $42^{\circ} \mathrm{C}$, twice in $0.1 \times \mathrm{SSC} / 0.1 \%$ SDS for $15 \mathrm{~min}$ at $65^{\circ} \mathrm{C}$. Membranes were exposed to $\mathrm{X}$-ray film with intensifying screens (Eastman Kodak (o., Rochester, NY) at $-80^{\circ} \mathrm{C}$ for $20 \mathrm{~h}$. The intensity of the ${ }^{32} \mathrm{P}$-labelled DNA-RNA hybridization was quantitated by scanning radioactivity of the membranes using an AMBIS Radioanalytic Imaging System (AMBIS, Inc., San Diego, CA). Membranes were hybridized first with $\left[{ }^{32} \mathrm{P}\right]$-labelled chicken cDNA encoding the LH $\beta$ subunit and the concentrations of mRNA were determined. The membranes were then stripwashed and rehybridized to $\left[{ }^{32} \mathrm{P}\right]-$ labelled chicken cDNA encoding the $\alpha$ subunit. As before the membranes were subsequently rehybridized to $\left[{ }^{32} \mathrm{P}\right]$-labelled chicken cDNA encoding $\beta$-actin. Concentrations of mRNA encoding each subunit were normalized to concentrations of mRNA encoding $\beta$-actin by dividing the radioactivity of the hormone probe by that of $\beta$-actin for each sample. In a preliminary experiment, graded amounts of total RNA from 1 to $20 \mu \mathrm{g}$ were used for the quantification analysis. The intensity of radioactivity increased in relation to the concentration of total RNA. Five micrograms of total RNA were determined to be optimal for the quantification of the mRNAs.

\section{Radioimmunoassay of $L H$ and oestradiol}

Plasma and pituitary concentrations of $\mathrm{LH}$ were determined by radioimmunoassay using chicken $\mathrm{LH}$ antigen (USDA-cLHI-1) and chicken LH antibody (USDA-AcLH-5) (kind gifts from J. A. Proudman, USDA) according to Krishnan et al. (1994). Samples were assayed in a single assay to eliminate interassay variation. The intra-assay variation for $\mathrm{LH}$ was $8.6 \%$ and the minimum standard concentration for $\mathrm{LH}$ was $0.39 \mathrm{ng} \mathrm{ml}^{-1}$. Concentrations of protein in the pituitary gland were determined by the method of Lowry et al. (1951).

Plasma concentrations of oestradiol were determined in duplicate according to the method described by Etches and Cheng (1981) using $\left[2,4,6,7-{ }^{3} \mathrm{H}\right]$-oestradiol (Amersham) and specific antibody for oestrogen (provided by R. J. Etches, University of Guelph, Canada). The radioimmunoassay was conducted in a single assay and the intra-assay coefficient of variation was $1.78 \%$ and the minimum standard concentration for oestradiol was $3.9 \mathrm{pg} \mathrm{ml}^{-1}$.

\section{Statistical analyses}

All data were analysed using one-way analysis of variance followed by Duncan's multiple range test. Significance was achieved when $P<0.05$.

\section{Results}

Northern blot hybridization analysis

A representative autoradiograph of northern blot analysis of chicken mRNAs encoding the LH $\beta$ and $\alpha$ subunits and $\beta$-actin Downloaded from Bioscientifica.com at 04/26/2023 11:04:38AM 


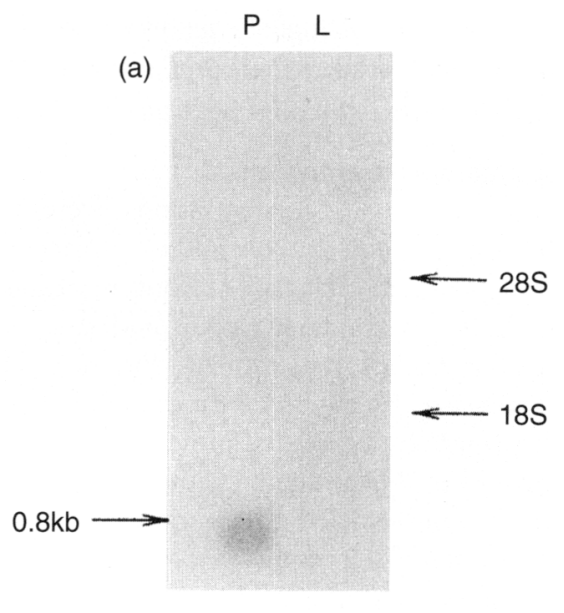

(b)

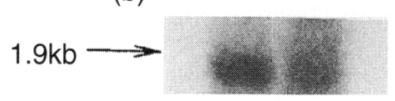

(c)

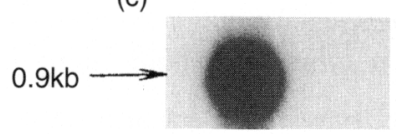

Fig. 1. Northern blot analysis of mRNAs encoding (a) the LH $\beta$ subunit, (b), $\beta$-actin and (c) the $\alpha$ subunit from the anterior pituitary gland $(\mathrm{P})$ and the liver $(\mathrm{L})$ of laying hens. Total RNA $(5 \mu \mathrm{g})$ was fractionated by electrophoresis in $1.2 \%(\mathrm{w} / \mathrm{v})$ agarose gel. The positions of $28 \mathrm{~S}$ and $18 \mathrm{~S}$ ribosomal RNAs are shown on the right side; those of mRNAs encoding the LH $\beta$ and $\alpha$ subunits and $\beta$-actin are shown on the left side.

is shown (Fig. 1). Single transcripts of $0.8 \mathrm{~kb}$ for mRNA encoding the $\mathrm{LH} \beta$ subunit, $1.9 \mathrm{~kb}$ for mRNA encoding $\beta$-actin and $0.9 \mathrm{~kb}$ for mRNA encoding the $\alpha$ subunit were detected in the pituitary gland. In the liver, only mRNA encoding $\beta$-actin was observed. These data were in accordance with the published data (Noce et al., 1989; Petrowski et al., 1993; Kubokawa et al., 1994), and confirmed the specificity of our methodology.

Changes in body, oviductal and ovary weight, plasma and pituitary concentrations of $L H$ and $m R N A$ s encoding $L H \beta$ and a subunits during the development in hens

Plasma and pituitary concentrations of LH and concentrations of mRNAs encoding the $\alpha$ subunit and LH $\beta$ subunit were determined in order to demonstrate gonadotrophin ontogeny during development in hens (Fig. 2). Body, oviductal and ovarian weights were also recorded. The birds laid their first egg between 133 and 145 days of age. Bodyweight increased progressively about fivefold during the examined period. Oviductal and ovarian weights increased about tenfold from 1 month to 4 months of age, but only the increase between 4 and 5 months was significant.

Plasma concentrations of LH showed similar changes to pituitary concentrations of $\mathrm{LH}$ and these $\mathrm{LH}$ concentrations gradually increased to reach a maximum at 4 months of age. Concentrations of mRNA encoding the $\alpha$ subunit showed a significant rise only at 4 months of age when compared with
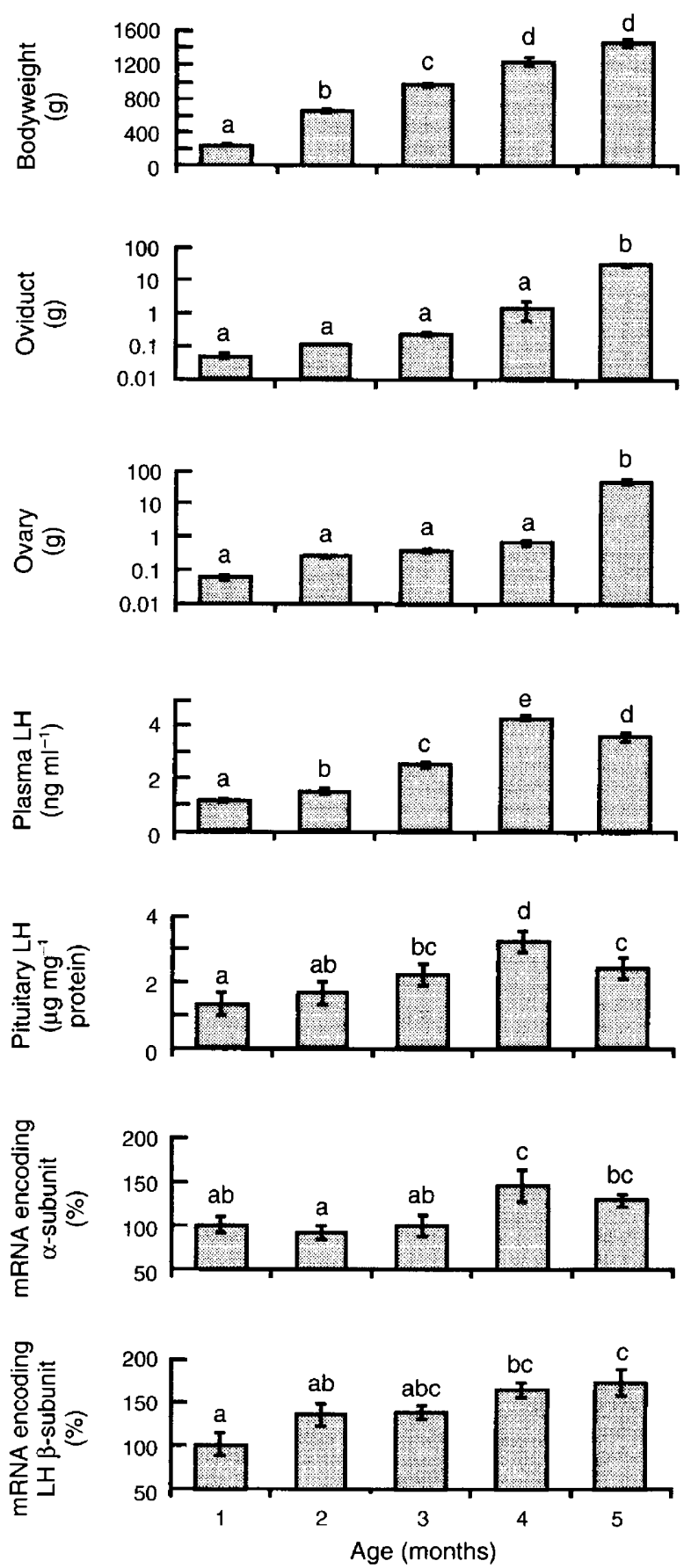

Fig. 2. Changes in body, oviductal and ovary weight, plasma and pituitary concentrations of LH, and steady-state pituitary concentrations of mRNAs encoding the $\alpha$ and $\beta$ subunits of LH of female chickens before sexual maturity. The values are means \pm SEM for five to ten birds per group. Different letters indicate significant differences at $P<0.05$.

those at $1-3$ months $(P<0.05)$. Concentrations of mRNA encoding the LH $\beta$ subunit gradually increased during the growing period, but the values at 4 and 5 months were significantly different from those at 1 and $1-2$ months, respectively $(P<0.05)$. 

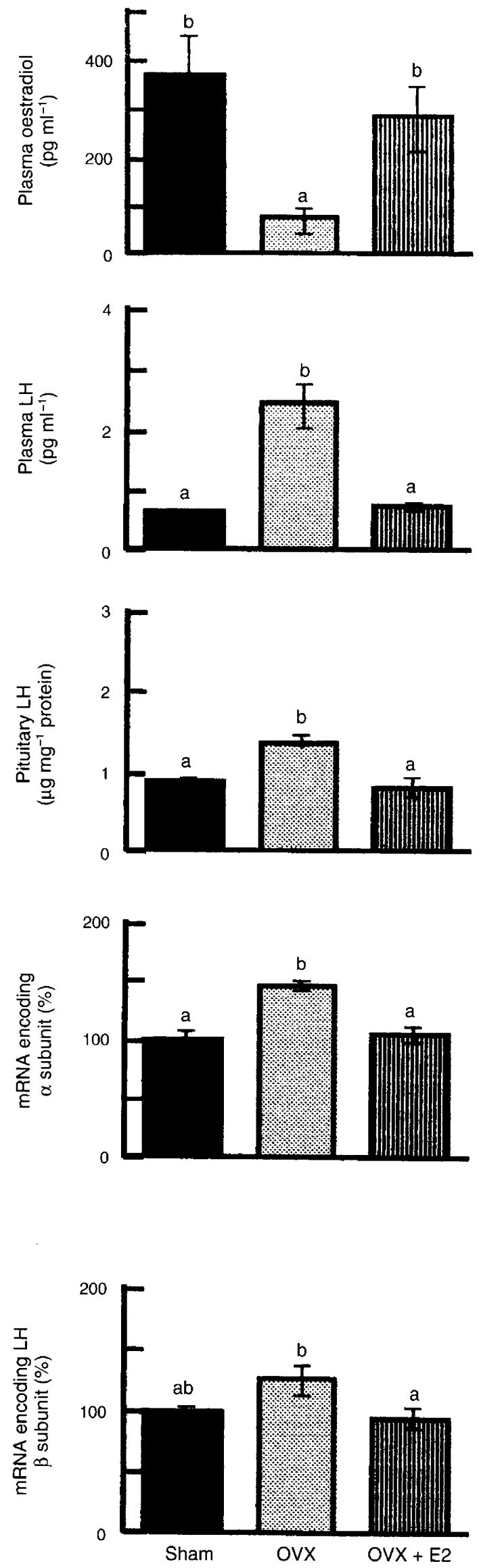

Effects of ovariectomy and oestradiol replacement on plasma and pituitary $L H$ concentrations and concentrations of $m R N A s$ encoding the LH $\beta$ and a subunits in 3-week-old pullets

Plasma oestradiol concentrations decreased markedly in the ovariectomized group but concentrations were restored to those of the sham group by oestradiol replacement in the OVX-E2 group (Fig. 3). Plasma LH concentrations increased threefold in the ovariectomized group and this increase was prevented by oestradiol replacement. Pituitary LH concentrations also increased by about 1.5 times in the ovariectomized group and treatment by oestradiol prevented this increase. The concentrations of mRNA encoding the $\alpha$ subunit increased twofold in the ovariectomized group and this increase was also prevented by oestradiol. In contrast, concentrations of mRNA encoding the $\beta$ subunit tended to increase in the ovariectomized group but these increased concentrations were not significantly different from those in the sham group.

Effects of ovariectomy and oestradiol replacement on plasma and pituitary $L H$ concentrations and concentrations of $m R N A s$ encoding the $L H \beta$ and a subunits in adult laying hens

In adult hens, ovariectomy treatment also caused a marked decrease in plasma concentrations of oestradiol but the concentrations returned fully to those of the sham group after oestradiol treatment (Fig. 4). Plasma and pituitary concentrations of LH increased significantly $(P<0.05)$ after ovariectomy (Fig. 4). Ovariectomized hens also exhibited a significant increase in concentrations of the mRNAs encoding the LH $\beta$ and $\alpha$ subunits when compared with their corresponding intact control $(P<0.05$, Fig. 4). Replacement of oestradiol at the time of ovariectomy prevented these increases.

\section{Discussion}

The present study clearly demonstrates that steady-state concentrations of mRNAs encoding the LH $\beta$ subunit and the common $\alpha$ subunit increase significantly, shortly before sexual maturity and were highly correlated with increases in plasma and pituitary concentrations of LH. These increases in plasma concentrations of LH before sexual maturity are consistent with previous reports (Senior, 1974; Sharp, 1975; Williams and Sharp, 1977; Sharp et al., 1977; Tanabe et al., 1981; Itoh et al., 1988).

The results reported here have confirmed that ovariectomy increases circulating concentrations of $\mathrm{LH}$ as well as increasing concentrations of mRNA encoding the LH $\beta$ subunit in the pituitary gland of chickens as was shown in domestic turkeys (Petrowski et al., 1993). Furthermore, this study demonstrates that the above changes are significantly correlated with the

Fig. 3. Effects of ovariectomy $(\mathrm{OVX})$ and oestradiol replacement $(\mathrm{OVX}+\mathrm{E} 2)$ on plasma concentrations of oestradiol and LH, pituitary concentrations of $\mathrm{LH}$ and steady-state pituitary concentrations of mRNAs encoding the LH $\beta$ and $\alpha$ subunits in 3-week-old female chickens. The values are means \pm SEM for four to five birds per group. Different letters indicate significant differences at $P<0.05$. 

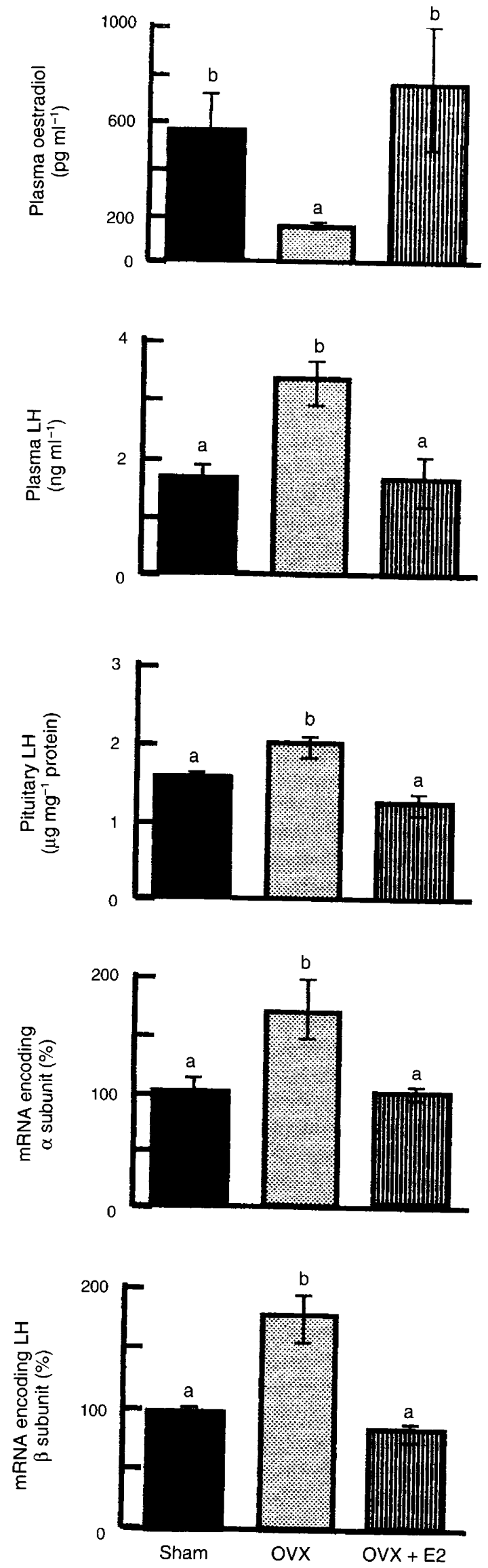

increase in pituitary LH concentrations as well as with concentrations of mRNA encoding the $\alpha$ subunit. In addition, such a change was not only evident in adult chickens, but also in young (3-week-old) chickens. However, in contrast to adult chickens, concentrations of mRNA encoding the LH $\beta$ subunit did not increase significantly in young chickens after ovariectomy. The reason for this difference between young and adult is not known. It is possible that the inhibition of LH synthesis by oestradiol has an age-related sensitivity to steroid feedback signals as has been observed in mammals.

Oestradiol replacement after ovariectomy was shown to inhibit plasma and pituitary LH concentrations and concentrations of mRNAs encoding the LH $\beta$ and $\alpha$ subunits. These data suggest that oestradiol inhibits both LH release and synthesis. In an in vitro study, King et al. (1989) demonstrated that oestradiol inhibits only LH release and not LH synthesis. The reason for this discrepancy between in vitro and in vivo results is uncertain. A possible interpretation is that the suppressive effect of oestradiol may be mediated by changes in $\mathrm{GnRH}$ secretion. Indeed, in mammals, there are some reports that oestradiol affects both GnRH pulse pattern and concentrations of mRNA encoding the pituitary GnRH receptor (Levine and Ramirez, 1982; Kaiser et al., 1993). Furthermore, Fallest et al. (1995) demonstrated that a GnRH antagonist inhibited ovariectomy-induced expression of mRNA encoding the $\mathrm{LH} \beta$ subunit in a similar manner to oestradiol replacement. In chickens, oestradiol receptors are located in both the hypothalamus and pituitary gland (Kawashima et al., 1987). Therefore, it is likely that oestradiol interacts at both the hypothalamus and pituitary gland to modulate concentrations of LH. At the pituitary gland, oestradiol may inhibit only $\mathrm{LH}$ release, whereas, at the hypothalamus, oestradiol may modulate $\mathrm{GnRH}$ release. A decrease in $\mathrm{GnRH}$ pulse frequency or amplitude could explain the observed inhibition of the mRNAs encoding the LH $\beta$ and $\alpha$ subunits and LH synthesis.

In the study reported here, it is clearly shown that pituitary concentrations of mRNA encoding the common $\alpha$ subunit were increased in response to ovariectomy. A reduction in circulating concentrations of oestradiol after ovariectomy may have provoked LH production by stimulating the production of both the LH $\beta$ subunit and the common $\alpha$ subunit. The $\alpha$ subunit, however, is also common to FSH, although little is known about feedback regulation of FSH release and synthesis in birds. Therefore, whether the increased expression of the $\alpha$ subunit is also associated with increased synthesis and release of FSH is unknown. However, Johnson et al. (1993) showed that removal of preovulatory follicles is associated with an acute increase and decrease in circulating concentrations of FSH and inhibin, respectively. Thus, FSH synthesis and release would be expected to increase after ovariectomy, as has been observed in mammals (Papavasiliou et al., 1986). Whether the suppression of mRNA encoding the common $\alpha$ subunit by oestradiol

Fig. 4. Effects of ovariectomy $(O V X)$ and oestradiol replacement $(\mathrm{OVX}+\mathrm{E} 2)$ on plasma concentrations of oestradiol and LH, pituitary concentrations of $\mathrm{LH}$ and steady-state pituitary concentrations of mRNAs encoding the LH $\beta$ and $\alpha$ subunits in adult laying hens. The values are means \pm SEM for four to five birds per group. Different letters indicate significant differences at $P<0.05$. 
replacement is reflected by a change in FSH concentrations awaits further investigation.

In summary, the results reported here show that concentrations of mRNAs encoding both the LH $\beta$ and $\alpha$ subunits increase after ovariectomy in adult laying hens and that oestradiol replacement prevents these increases in mRNA concentrations. The increase in plasma and pituitary LH concentrations after ovariectomy and the decreased concentrations when oestradiol replacement treatment is given are highly correlated with concentrations of these mRNAs. Thus transcription of both the $\alpha$ and $\beta$ subunits of pituitary LH appears to be regulated during the negative feedback of pituitary synthesis of oestradiol.

The authors thank S. Ishii (Waseda University, Tokyo) for providing chicken cDNA encoding the LH $\beta$ subunit, D. N. Foster (University of Minnesota, St. Pauls, MI) for chicken cDNA encoding the $\alpha$ subunit, J. A. Proudman (USDA, Beltsville, MD) for chicken LH and chicken LH antibody, K. Wakabayashi (Gunma University, Maebashi) for goat anti-rabbit IgG, R. J. Etches (University of Guelph, Guelph) for oestradiol antibody, and the Radioisotope Center of Nagoya University for the use of the AMBIS Radioanalytic Image System. This research was supported in part by a Grant-in-Aid from Monbusho International Scientific Research Program (Joint Research; 07044190) to K. Shimada.

\section{References}

Chomczynski P and Sacchi N (1987) Single-step method of RNA isolation by acid guanidium thiocyanate-phenol-chloroform extraction Analytical Biochemistry $162156-159$

Etches RJ and Cheng KW (1981) Changes in the plasma concentrations of luteinizing hormone, progesterone, oestradiol and testosterone and in the binding of follicle-stimulating hormone to the theca of follicles during the ovulation cycles of the hen (Gallus domesticus) Journal of Endocrinology 91 $11-22$

Fallest PC, Trader GL, Darrow JM and Shupnik MA (1995) Regulation of rat luteinizing hormone $\beta$ gene expression in transgenic mice by steroids and a gonadotropin-releasing hormone antagonist Biology of Reproduction $\mathbf{5 3}$ 103-109

Foster DN, Galehouse D, Giordano T, Min B, Lamb IC, Porter DA, Intehar KJ and Bacon WL (1992) Nucleotide sequence of the CDNA encoding the common a-subunit of the chicken pituitary glycoprotein hormones Journal of Molecular Endocrinology 8 21-27

Haisenlender DJ, Dalkin AC and Marshall JC (1993) Regulation of gonadotropin gene expression. In The Physiology of Reproduction 2nd Edn pp 1793-1813 Eds E Knobil and JD Neill. Raven Press, Ltd, New York

Itoh H, Kono T, Kuwayama T and Ichinoe K (1988) The relationship between plasma concentration of progesterone, estradiol and testosterone and the ages of first egg laying in maturing pullets Japanese Poultry Science 25 86-92

Johnson PA, Brooks C, Wang SY and Chen CC (1993) Plasma concentrations of immunoreactive inhibin and gonadotropins following removal of ovarian follicles in the domestic hen Biology of Reproduction 49 1026-1031

Kaiser UB, Jakubowial A, Steinberger A and Chen WW (1993) Regulation of rat pituitary gonadotropin-releasing hormone receptor mRNA levels in vivo and in vitro. Endocrinology $133931-934$
Kansaku N, Shimada K, Terada O and Saito N (1994) Prolactin, growth hormone, and luteinizing hormone- $\beta$ subunit gene expression in the cephalic and caudal lobes of the anterior pituitary gland during embryogenesis and different reproductive stages in the chicken General and Comparative Endocrinology 96 197-205

Kawashima M, Kamiyoshi M and Tanaka K (1987) Presence of estrogen receptors in the hen hypothalamus and pituitary Endocrinology $\mathbf{1 2 0}$ $582-588$

King JA, Davidson JS, Mehl AEI, Wakefield IK, Andersson P-B and Millar RP (1989) Gonadal steroid modulation of signal transduction and luteinizing hormone release in cultured chicken pituitary cells Endocrinology 124 1830-1840

Krishnan KA, Proudman JA and Bahr JM (1994) Purification and partial characterization of isoforms of luteinizing hormone from the chicken pituitary gland Comparative Biochemistry and Physiology 108B 253-264

Kubokawa K, Ishii S and Wingfield JC (1994) Effects of day length on luteinizing hormone $\beta$-subunit mRNA and subsequent gonadal growth in the whitecrowned sparrow, Zonotrichia leucophrys gambelii. General and Comparative Endocrinology 95 42-51

Levine JE and Ramirez VD (1982) LHRH release during the rat estrous cycle and after ovariectomy, as estimated with push-pull cannulae Endocrinology 111 1439-1444

Lowry OH, Rosebrough NJ, Farr AL and Randall RJ (1951) Protein measurement with the folin phenol reagent Journal of Biological Chemistry 193 265-275

Luck MR and Scanes CG (1980) lonic and endocrine factors influencing the secretion of luteining hormone by chicken anterior pituitary cells in vitro. General and Comparative Endocrinology 41 260-265

Noce T, Ando H, Ueda T, Kubokawa K, Higashinakagawa T and Ishii S (1989) Molecular cloning and nucleotide sequence analysis of the putative cDNA for the precursor molecule of the chicken LHß-subunit Journal of Molecular Endocrinology 3 129-137

Papavasiliou SS, Herbon AZL, Duncan-Weldon J, Marshall JC and Landefeld TD (1986) $\alpha$ and luteinizing hormone $\beta$ messenger ribonucleic acid (RNA) of male and female rats after castration: quantitation using an optimized RNA dot blot hybridization assay Endocrinology 119 691-698

Petrowski ML, Wong EA, Ishii S and El Halawani ME (1993) Influence of ovariectomy and photostimulation on luteinizing hormone in the domestic turkey: evidence for differential regulation of gene expression and hormone secretion Biology of Reproduction 49 295-299

Senior BE (1974) Oestradiol concentrations in the peripheral plasma of the domestic hen from 7 weeks of age until the time of sexual maturity Journal of Reproduction and Fertility 41 107-112

Sharp PJ (1975) A comparison of variations in plasma luteinizing hormone concentrations in male and female domestic chickens (Gallus domesticus) from hatch to sexual maturity Journal of Endocrinology 67 211-223

Sharp PJ, Culbert J and Wells JW (1977) Variations in steroid and plasma concentrations of androgens and luteinizing hormone during sexual development in the cockerel Journal of Endocrinology 74 467-476

Shimada K, Ishida H, Sato K, Seo H and Matsui N (1991) Expression of prolactin gene in incubating hens Journal of Reproduction and Fertility 91 147-154

Tanabe Y, Nakamura T, Tanase H and Doi $\mathbf{O}$ (1981) Comparisons of plasma LH, progesterone, testosterone and estradiol concentrations in male and female chickens (Gallus domesticus) from 28 to 1141 days of age Endocrinologia Japonica 28 605-613

Williams JC and Sharp PJ (1977) A comparison of plasma progesterone and luteinizing hormone in growing hens from eight weeks of age to sexual maturity Journal of Endocrinology 75 447-448

Wilson SC and Sharp PJ (1976) Induction of luteinizing hormone release by gonadal steroids in the ovariectomized hen Journal of Endocrinology $\mathbf{7 1}$ $87-98$ 